\title{
Paenibacillus azotofixans (Seldin et al. 1984) Ash et al. 1995 does not have priority over Paenibacillus durum (Smith and Cato 1974) Collins et al. 1994 : request for an opinion
}

\author{
N. A. Logan, ${ }^{1}$ M. Heyndrickx, ${ }^{2}+$ R. C. W. Berkeley ${ }^{3}$ and P. De $\operatorname{Vos}^{2}$ \\ Author for correspondence: N. A. Logan. Tel: +44 141331 3207. Fax: +44 141331 3208/3242. \\ e-mail: N.A.Logan@gcal.ac.uk
}

1 Department of Biological Sciences, Glasgow Caledonian University, Cowcaddens Road, Glasgow G4 OBA, UK

2 Laboratorium voor Microbiologie, Universiteit Gent, K. L. Ledeganckstraat 35 B-9000 Gent, Belgium

3 Badock Hall, University of Bristol, Stoke Park Road, Bristol BS9 1JQ, UK

\section{We propose that the organism described by Seldin et al. (1984), which is based on the type strain ATCC 35681 , should continue to be called Paenibacillus azotofixans although, with the reclassification of Paenibacillus durum as a member of Paenibacillus azotofixans, the epithet durum has priority.}

Keywords: Paenibacillus azotofixans, Paenibacillus durum
In the April 1997 issue of the IJSB, a paper entitled 'Reclassification of Paenibacillus durum (formerly Clostridium durum Smith and Cato 1974) Collins et al. 1994 as a member of the species P. azotofixans (formerly Bacillus azotofixans Seldin et al. 1984) Ash et al. 1994' was published (6). In that paper the authors presented phenotypic and genotypic evidence that their five strains of Paenibacillus azotofixans and two strains of $P$. durum belong to the same species, a conclusion not inconsistent with the findings of Collins et al. (2) and Heyndrickx et al. (3) for strains of these species. However, the reclassification of $P$. durum as $P$. azotofixans (6) does not follow the principle of priority (Rule 24a) of the International Code of Nomenclature of Bacteria (5). Clostridium durum was published in 1974 (9) and included in the Approved Lists of Bacterial Names (8). So according to Rule 23a, Note 1, of the Code (5) the species epithet durum has priority over azotofixans which was not published until 1984 (7).

According to Rosado et al. (6), the epithet azotofixans has priority over the epithet durum because the transfer of Bacillus azotofixans to Paenibacillus (1) pre-dated the transfer of Clostridium durum to Paenibacillus (2). Such a transfer does not effect priority, but even if it did the transfer of Bacillus azotofixans to Paenibacillus was not validated, according to Rules 27 and 28 a of the Code, until its appearance in Validation List no. 52 in

† Present address: Government Dairy Research Station, Brusselsesteenweg 370, B-9090 Melle, Belgium.
January 1995 (4), whereas the transfer of Clostridium durum was validly published in 1994 (2).

However, as the junior synonym azotofixans is far more informative than the senior synonym durum, the opinion of the Judicial Commission is sought on whether the junior synonym (azotofixans) could be conserved (Rules 23a and 56b of the Code).

\section{References}

1. Ash, C., Priest, F. G. \& Collins, M. D. (1993). Molecular identification of rRNA group 3 bacilli (Ash, Farrow, Wallbanks and Collins) using a PCR probe test. Antonie Leeuwenhoek 64, 253-260.

2. Collins, M. D., Lawson, P. A., Willems, A., Cordoba, J. J., Fernandez-Garayzabal, J., Garcia, P., Cai, J., Hippe, H. \& Farrow, J. A. E. (1994). The phylogeny of the genus Clostridium: proposal of five new genera and eleven new species combinations. Int J Syst Bacteriol 44, 812-826.

3. Heyndrickx, M., Vandemeulebroecke, K., Scheldeman, P., Kersters, K., De Vos, P., Logan, N. A., Aziz, A. M., Ali, N. \& Berkeley, R. C. W. (1996). A polyphasic reassessment of the genus Paenibacillus, reclassification of Bacillus lautus (Nakamura 1984) as Paenibacillus lautus comb. nov. and of Bacillus peoriae (Montefusco et al. 1993) as Paenibacillus peoriae comb. nov. Emended descriptions of $P$. lautus and of $P$. peoriae. Int J Syst Bacteriol 46, 988-1003.

4. International Committee on Systematic Bacteriology (1995). Validation of the publication of new names and combinations previously effectively published outside the IJSB. List no. 52. Int J Syst Bacteriol 45, 197-198.

5. Lapage, S. P., Sneath, P. H. A., Lessel, E. F., Skerman, V. B. D., 
Seeliger, H. P. R. \& Clark, W. A. (editors) (1992). International Code of Nomenclature of Bacteria (1990 Revision). Washington, DC: American Society for Microbiology.

6. Rosado, A. S., van Elsas, J. D. \& Seldin, L. (1997). Reclassification of Paenibacillus durum (formerly Clostridium durum Smith and Cato 1974) Collins et al. 1994 as a member of the species P. azotofixans (formerly Bacillus azotofixans Seldin et al. 1984) Ash et al. 1994. Int J Syst Bacteriol 47, 569-572.
7. Seldin, L., van Elsas, J. D. \& Penido, E. G. C. (1984). Bacillus azotofixans sp. nov., a nitrogen-fixing species from Brazilian soils and grass roots. Int $J$ Syst Bacteriol 34, 451-456.

8. Skerman, V. B. D., McGowan, V. \& Sneath, P. H. A. (1980). Approved lists of bacterial names. Int $J$ Syst Bacteriol 30, 225-420.

9. Smith, L. D. S. \& Cato, E. P. (1974). Clostridium durum sp. nov., the predominant organism in a sediment core from the Black Sea. Can J Microbiol 20, 1393-1397. 